\title{
Arlington Heights Won in the Supreme Court but the Fair Housing Act's Goal of Promoting Racial Integration Saved the Low-Income Housing
}

Henry Rose

Follow this and additional works at: https://digitalcommons.tourolaw.edu/lawreview

Part of the Civil Rights and Discrimination Commons, Fourteenth Amendment Commons, Housing Law Commons, and the Law and Race Commons

\section{Recommended Citation}

Rose, Henry (2019) "Arlington Heights Won in the Supreme Court but the Fair Housing Act's Goal of Promoting Racial Integration Saved the Low-Income Housing," Touro Law Review. Vol. 35: No. 2, Article 8. Available at: https://digitalcommons.tourolaw.edu/lawreview/vol35/iss2/8

This Article is brought to you for free and open access by Digital Commons @ Touro Law Center. It has been accepted for inclusion in Touro Law Review by an authorized editor of Digital Commons @ Touro Law Center. For more information, please contact Iross@tourolaw.edu. 


\title{
Arlington Heights Won In the Supreme Court But the Fair Housing Act's Goal of Promoting Racial INTEGRATION SAVED THE LOW-INCOME HOUSING
}

\author{
Henry Rose*
}

\section{INTRODUCTION}

In the early 1970s, a developer sought a zoning change to a parcel of land in Arlington Heights, Illinois that would allow for the construction of low-income housing. Arlington Heights denied the zoning change and the developer sued Arlington Heights arguing that this denial violated both equal protection under the Fourteenth Amendment of the United States Constitution and the federal Fair Housing Act ("FHA"). The case reached the United States Supreme Court on the equal protection issue and the Court held that the developer did not establish an equal protection violation because it failed to prove that a racially discriminatory purpose motivated Arlington Heights' denial of the zoning change. The Supreme Court remanded the case to the lower courts to consider the FHA claims. ${ }^{1}$

On remand from the Supreme Court, the Seventh Circuit Court of Appeals held that the denial of the zoning change that the developer sought from Arlington Heights had the discriminatory effect of perpetuating residential racial segregation there, and unless the lowincome housing project could feasibly be built at another site in Arlington Heights, the denial of the zoning change constituted a violation of the FHA. ${ }^{2}$ After this decision by the Seventh Circuit, the parties entered into a consent decree in which Arlington Heights agreed to annex another parcel of land and allow the construction of

* Curt and Linda Rodin Professor of Law and Social Justice, Loyola University Chicago School of Law.

1 The case discussed in the paragraph came from Village of Arlington Heights $v$. Metropolitan Housing Development Corp., 429 U.S. 252 (1977).

2 Metro. Hous. Dev. Corp. v. Vill. of Arlington Heights, 558 F.2d 1283 (7th Cir. 1977), cert denied, 434 U.S. 1025 (1978). 
the developer's low-income housing project on it. ${ }^{3}$ The developer's project was eventually built on the land that Arlington Heights annexed, and the low-income housing project opened to a diverse population of residents in 1983.

The construction of the developer's low-income housing project in Arlington Heights was facilitated by the Seventh Circuit's decision that a denial of housing that has the discriminatory effect of perpetuating residential racial segregation violates the FHA even if a discriminatory purpose is not established. In 2013, the federal Department of Housing and Urban Development ("HUD") issued a rule that the FHA could be violated by, inter alia, housing decisions that have the discriminatory effect of perpetuating residential segregation. ${ }^{4}$ In 2015, the United States Supreme Court determined that a housing policy that has a disproportionately adverse effect on minorities and otherwise lacks a legitimate rationale is cognizable under the FHA. ${ }^{5}$

The purpose of this article is to analyze how the Seventh Circuit's decision in the Arlington Heights case is an important judicial precedent for using the FHA to challenge housing decisions that perpetuate housing segregation. The article seeks to explain how the Seventh Circuit's decision that Arlington Heights must accommodate the construction of low-income housing in order to comply with the FHA presages interpretations of the FHA by both HUD and the Supreme Court that occurred more than 35 years later. These broad interpretations of the FHA create valuable tools to achieve one of the primary goals of the FHA - the residential integration of the races in the United States. Finally, this article will address 2018 efforts by HUD to review its 2013 discriminatory effect rule in light of the Supreme Court's 2015 decision. This article will examine whether HUD's current regulatory review process should alter how the discriminatory effect standard involving the perpetuation of residential segregation will be applied in the future to determine whether the FHA has been violated.

3 Metro. Hous. Dev. Corp. v. Vill. of Arlington Heights, 469 F. Supp. 836 (N.D. Ill. 1979).

4 Implementation of the Fair Housing Act's Discriminatory Effects Standard, 78 Fed. Reg 11460-501 (Feb. 15, 2013).

5 Tex. Dep't. of Hous. \& Cmty. v. Inclusive Cmtys. Project, Inc., 135 S. Ct. 2507 (2015). 


\section{BaCkground of THE ARLington Heights CASE}

\section{A. Village of Arlington Heights, Illinois}

Arlington Heights is a suburb of Chicago, Illinois that is located approximately 26 miles northwest of Chicago's downtown. ${ }^{6}$ In 1970, the population of Arlington Heights was 64,884, of whom 27 residents were black. ${ }^{7}$ Only 137 of the 13,000 persons who worked in Arlington Heights in 1970 were black and almost all of these 137 blacks lived in Chicago. ${ }^{8}$ The northwest suburban townships of Chicago, of which Arlington Heights is a part, experienced a population increase of 219,000 people from 1960 to 1970 but only 170 of the new residents were black. ${ }^{9}$ During the same time period, the proportion of the black population in the Chicago metropolitan area increased from $14 \%$ to $18 \% .^{10}$

\section{B. Clerics of St. Viator (Clerics)}

The Clerics of St. Viator ("Clerics"), a Catholic religious order, owned 80 acres of land in Arlington Heights on which they operated a novitiate and a high school. ${ }^{11}$ The Clerics' 80 acre parcel of land was surrounded by single family homes. ${ }^{12}$ Most of the 80 acres were vacant land, and the Clerics decided in 1970 to devote some of this vacant land to low- and moderate-income housing. ${ }^{13}$

\section{Metropolitan Housing Development Corporation (MHDC)}

The Metropolitan Housing Development Corporation ("MHDC") is an Illinois not-for-profit corporation that was created in 1968 to develop low- and moderate-income housing in the Chicago metropolitan area. ${ }^{14}$ In 1970, the Clerics entered into an agreement to

\footnotetext{
6 Vill. of Arlington Heights v. Metro. Hous. Dev. Corp., 429 U.S. 252, 255 (1977).

7 Metro. Hous. Dev. Corp., 558 F.2d at 1286-87.

8 Metro. Hous. Dev. Corp. v. Vill. of Arlington Heights, 517 F.2d 409, 414 n.2 (7th Cir. 1975).

9 Id. at 414.

$10 \mathrm{Id}$.

11 Id. at 411.

12 Vill. of Arlington Heights v. Metro. Hous. Dev. Corp., 429 U.S. 252, 255 (1977).

13 Id.

14 Metro. Hous. Dev. Corp., 517 F.2d at 410-11.
} 
sell 15 of their 80 acres to MHDC at the bargain price of $\$ 300,000$, contingent upon MHDC securing a zoning change from Arlington Heights and obtaining financial assistance from the federal government to build subsidized housing that would be racially integrated. ${ }^{15}$ MHDC developed plans to build Lincoln Green, 20 twostory buildings totaling 190 residential units with a mix of single bedroom and multiple bedroom units, on the 15 acre site. ${ }^{16}$

\section{Arlington Heights Zoning Law}

Most of the land in Arlington Heights was zoned for detached single family homes. ${ }^{17}$ The 80 acre parcel owned by the Clerics as well as all of the land bordering it was zoned R-3, limiting its use to single family homes. ${ }^{18}$ In order for Lincoln Green to be built by MHDC, the 15 acres that MHDC bought from the Clerics needed to be rezoned R5, allowing for the construction of multifamily units. ${ }^{19}$ The 1959 Comprehensive Plan of Arlington Heights provided that land should only be zoned R-5 as a buffer between single family homes and commercial, industrial or other high intensity uses. ${ }^{20}$ In the early 1970s, there were 60 tracts of land in Arlington Heights that were zoned R-5 and some of them were vacant land. ${ }^{21}$

MHDC applied to Arlington Heights for a zoning change from R-3 to R-5 for the 15 acre parcel it bought from the Clerics to allow for the construction of Lincoln Green there. ${ }^{22}$ MHDC worked with the Arlington Heights staff in a preliminary review process and every change recommended by the staff during these consultations was incorporated into the rezoning application that MHDC submitted to the Plan Commission. ${ }^{23}$ The Plan Commission considered MHDC's rezoning application at three public meetings in the spring of 1971 that drew large crowds. ${ }^{24}$ The public comments at these meetings were

15 Vill. of Arlington Heights, 429 U.S. at 256-57.

16 Id.

17 Id. at 255.

18 Metro. Hous. Dev. Corp., 517 F.2d at 411.

19 Id.

20 Id.

21 Metro. Hous. Dev. Corp. v. Vill. of Arlington Heights, 373 F. Supp. 208, 211 (N.D. Ill. 1974).

22 Metro. Hous. Dev. Corp., 517 F.2d. at 411.

23 Vill. of Arlington Heights v. Metro. Hous. Dev. Corp., 429 U.S. 252, 257 (1977).

24 Id. 
mixed, but many of the persons who attended them were both demonstrative and vocal in opposition to Lincoln Green. ${ }^{25}$ At the conclusion of its third meeting, the Plan Commission recommended, with two members dissenting, that the 15 acre parcel was not an appropriate location for low- and moderate-income housing. ${ }^{26}$ On September 28, 1971, the Village Board met to consider MHDC's rezoning application and the Plan Commission's recommendation, and after hearing from the public, the Board voted 6-1 to deny MHDC's rezoning application. ${ }^{27}$

\section{Litigation Challenging the Denial of MHDC'S REZONING APPLICATION bY ARLINGTON HEIGHTS}

\section{A. Plaintiffs' Complaint}

In June 1972, MHDC and three black persons sued Arlington Heights and several village officials in federal $\operatorname{cour}^{28}$ asserting that the denial of MHDC's rezoning application violated their rights under: the Civil Rights Act, 42 U.S.C. $\S \S 1981$, 1982, and 1983; the FHA, 42 U.S.C. § 3601 et seq.; and the Fourteenth Amendment of the United States Constitution. ${ }^{29}$ One black plaintiff, Mr. Ranson, worked in Arlington Heights but lived with his family approximately 20 miles away and alleged in the complaint that he would seek and qualify to live at Lincoln Green if it were built. ${ }^{30}$

\section{B. 1974 District Court Decision}

A district court judge conducted a trial on the merits of plaintiffs' case and concluded on February 22, 1974 that a judgment should be entered in favor of Arlington Heights and the other defendants. ${ }^{31}$ The district court judge found that defendants had not violated plaintiffs' Fourteenth Amendment rights because the denial of the zoning change disadvantaged low-income persons, not merely

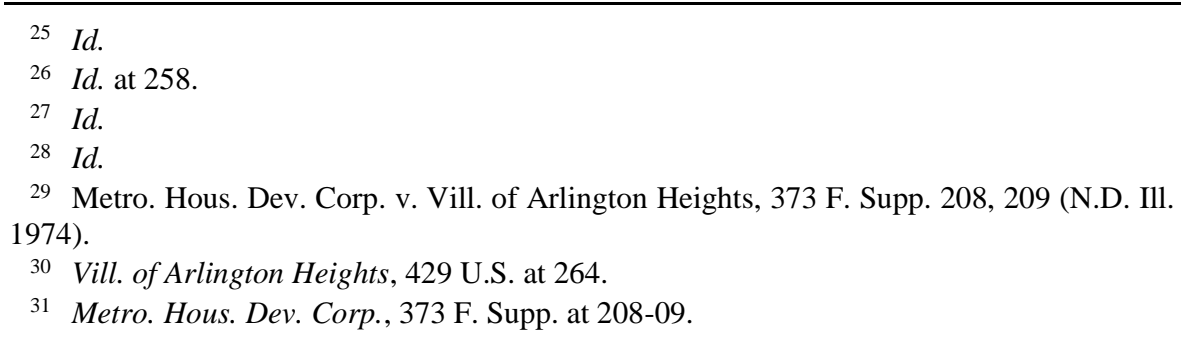


blacks, and the denial was motivated by a desire to protect property values and the integrity of Arlington Heights' zoning plan. ${ }^{32}$ The district court judge also ruled that no sections of the FHA "seem applicable to the facts of this case." 33

\section{1975 Seventh Circuit Court of Appeals Decision}

The plaintiffs appealed the 1974 district court decision and the Seventh Circuit Court of Appeals only considered whether Arlington Heights violated plaintiffs' equal protection rights by denying MHDC's rezoning request ${ }^{34}$ and did not address whether plaintiffs' rights under the FHA were violated. ${ }^{35}$ The court recognized that a greater percentage of blacks than whites would be adversely affected by the denial of MHDC's rezoning application by defendants because a greater percentage of blacks than whites would be financially eligible to live in Lincoln Green if it were constructed as planned. ${ }^{36}$ However, the court held that this racial disparity alone did not amount to racial discrimination. ${ }^{37}$ The court then considered that Arlington Heights had a small number of black residents (27 of 64,884 in 1970) and did not have any other existing or planned low-income housing developments and held that its rejection of the Lincoln Green proposal had the racially discriminatory effect of perpetuating residential racial segregation there..$^{38}$ The court further held that Arlington Heights' reasons for denying MHDC's rezoning request-maintaining the integrity of its zoning plan and protecting neighboring property values - were not sufficiently compelling interests to justify this racially discriminatory effect, and, therefore, Arlington Heights violated plaintiffs' equal protection rights when it denied the zoning change. ${ }^{39}$

32 Id. at 210-11.

33 Id. at 209.

34 Metro. Hous. Dev. Corp. v. Vill. of Arlington Heights, 517 F.2d 409, 410-15 (7th Cir. 1975).

35 Id. at 411-15.

$36 I d$. at 413.

$37 \mathrm{Id}$.

38 Id. at 413-15.

39 Id. at 415. 


\section{1977 United States Supreme Court Decision}

The defendants appealed the 1975 Seventh Circuit decision, and the United States Supreme Court reversed it and held that proof of discriminatory purpose is required to prove racial discrimination under equal protection. ${ }^{40}$ The Court acknowledged that proof of a racially discriminatory effect can be circumstantial evidence of racially discriminatory purpose. ${ }^{41}$ However, the Court found that plaintiffs failed to prove that a discriminatory purpose was a motivating factor in the decision of Arlington Heights to deny MHDC's request for a zoning change and, therefore, equal protection was not violated..$^{42}$ The Court remanded the case to the lower courts to address plaintiffs' claims under the FHA. ${ }^{43}$

\section{E. 1977 Seventh Circuit Court of Appeals Decision}

On remand, the 1977 Seventh Circuit decision initially noted that the Supreme Court had not reversed the holding in the 1975 Seventh Circuit decision that the denial of the zoning change by Arlington Heights had the racially discriminatory effect of perpetuating racial segregation there. ${ }^{44}$ The court then focused on whether Arlington Heights had violated 42 U.S.C. § 3604(a) of the FHA which provides that "it shall be unlawful ... to make unavailable or deny ... a dwelling to a person because of race, color, religion or national origin." ${ }^{45}$ The court held that a violation of 42 U.S.C. $\S$ 3604(a) can be established by proof of racially discriminatory effect without proof of racially discriminatory intent, although conduct that shows such an effect is not necessarily a violation of 42 U.S.C $\S$ 3604(a). ${ }^{46}$ Rather, whether conduct that causes such a discriminatory effect violates 42 U.S.C. § 3604(a) depends upon:

1. The strength of the discriminatory effect;

2. Any evidence of discriminatory intent;

40 Vill. of Arlington Heights v. Metro. Hous. Dev. Corp., 429 U.S. 252, 255, 265 (1977).

41 Id. at 266.

42 Id. at 265-71.

43 Id. at 271.

44 Metro. Hous. Dev. Corp. v. Vill. of Arlington Heights, 558 F.2d 1283, 1287-88 (7th Cir. 1977), cert denied, 434 U.S. 1025 (1978).

45 Id. at 1287.

46 Id. at 1290. 
3. Defendants' interest in the conduct that produced the discriminatory effect; and

4. Whether plaintiffs seek defendants to affirmatively provide housing for members of minority groups or to restrain defendants from interfering with property owners who wish to provide such housing. ${ }^{47}$

After considering these four factors, the court concluded that since plaintiffs were seeking to effectuate the FHA's goal of creating racially integrated housing, the denial of MHDC's rezoning application by Arlington Heights would constitute a violation of 42 U.S.C. $§ 3604(a)$ if there was no other land in Arlington Heights that was both properly zoned and suitable for federally subsidized, lowincome housing. ${ }^{48}$ As a result, the case was remanded to the district court to determine whether such other land was available in Arlington Heights and, if not, to find that Arlington Heights' denial of the zoning change that MHDC requested violated 42 U.S.C. $§ 3604(a){ }^{49}$ Defendants sought review of this 1977 decision of the Seventh Circuit in the United States Supreme Court but certiorari was denied. ${ }^{50}$

\section{F. 1979 District Court Decision}

After the Supreme Court denied certiorari review of the 1977 Seventh Circuit decision, the case was remanded to the district court for proceedings consistent with this decision of the Seventh Circuit. ${ }^{51}$ The parties notified the district court judge that they had negotiated a consent decree that they presented to the court for consideration. ${ }^{52}$ The proposed consent decree provided that a slightly modified low-income housing development would be built by MHDC on a 20 acre, vacant parcel of currently unincorporated land located between Arlington Heights and the neighboring Village of Mount Prospect. ${ }^{53}$ Under the terms of the proposed consent decree, Arlington Heights would annex

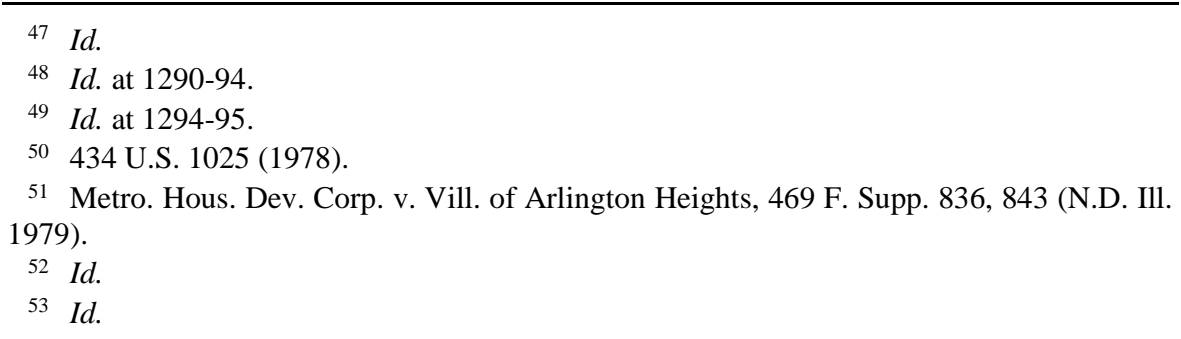


this land and would designate 12 acres of it as R-5 to allow for MHDC's construction of low-income housing on it. ${ }^{54}$ The new development would include 190 total rental units, 109 units suitable for elderly persons and the remaining units suitable for families. ${ }^{55}$ Mount Prospect, a few local civic organizations and several neighboring landowners were allowed to intervene in the case, and they all objected to the entry of the proposed consent decree. ${ }^{56}$ The court conducted three days of hearings on the intervenors' objections to the consent decree, considered their objections and dismissed them because they were overridden by strong federal policies that favor open housing and the settlement of litigation. ${ }^{57}$ After the intervenors were dismissed from the case, the district judge entered the consent decree. ${ }^{58}$ The intervenors appealed the entry of the consent decree to the Seventh Circuit Court of Appeals, and the entry of the consent decree was affirmed by the Seventh Circuit. ${ }^{59}$

\section{LINDEN Place DEVELOPMENT}

Pursuant to the settlement of the litigation, MHDC broke ground in 1980 on the construction of a new low-income housing development called Linden Place on the land that Arlington Heights annexed ${ }^{60}$ Linden Place opened for occupancy in 1983 with 109 units for senior citizens and 80 units for families. ${ }^{61}$ The first residents of Linden Place were approximately $60 \%$ white and the other residents were members of minority groups. ${ }^{62}$

${ }^{54} I d$. at 843,870 .

55 Id. at 871.

56 Id. at 836, 843-44, 847-48, 864-69.

57 Id. at $836,844-69$.

58 Id. at 869 .

59 Metro. Hous. Dev. v. Vill. of Arlington Heights, 616 F.2d 1006, 1007, 1015 (7th Cir. 1980).

60 Dori Meinert, Housing Accepted As Controversy Dies Down, CHI. TRIB., Aug. 31, 1983, ND17.

${ }^{61} I d$.

62 Steven Morris, Subsidized Housing a Boon For Many Suburbanites, Снг. TRIв., May 5 , 1984, W1. 


\section{THE SignificANCE OF THE INTERPRETATIONS OF THE FHA IN THE 1977 SEVENTH CIRCUIT DECISION}

After the Supreme Court held that plaintiffs had not established an equal protection violation because they failed to prove that defendants had acted with discriminatory purpose in denying MHDC's rezoning request ${ }^{63}$ the Supreme Court remanded the case to consider plaintiffs' contention that the rezoning denial violated the FHA. ${ }^{64}$ The Seventh Circuit panel that considered the case on remand from the Supreme Court in 1977 initially recognized that the Supreme Court had not reversed the 1975 Seventh Circuit holding that the denial of rezoning by defendants had a racially discriminatory effect. ${ }^{65}$ Accordingly, the Seventh Circuit panel considering the case on remand in 1977 reaffirmed the 1975 Seventh Circuit holding that defendants' denial of rezoning had the discriminatory effect of perpetuating racial residential segregation in Arlington Heights. ${ }^{66}$ The Seventh Circuit panel on remand then addressed whether a racially discriminatory effect, without proof of discriminatory intent, could violate the FHA. ${ }^{67}$ The panel analyzed the history, language and purpose of the FHA and held that a discriminatory effect could constitute a violation of the FHA. ${ }^{68}$ The Seventh Circuit joined the Eighth Circuit in so holding. ${ }^{69}$ Another significant aspect of the 1977 Seventh Circuit decision is how the court analyzed the discriminatory effect of defendants' decision to deny MHDC's rezoning request. The court identified two types of racially discriminatory effects which a facially neutral decision about housing can produce..$^{70}$ The first type of discriminatory effect occurs if the decision has a greater adverse impact on one racial group than on another. ${ }^{71}$ The second type of discriminatory effect occurs if the decision perpetuates racial segregation in a community

63 Vill. of Arlington Heights v. Metro. Hous. Dev. Corp., 429 U.S. 252, 270-71 (1977).

${ }_{64} I d$. at 271.

65 Metro. Hous. Dev. Corp. v. Vill. of Arlington Heights, 558 F.2d 1283, 1287 (7th Cir. 1977), cert denied, 434 U.S. 1025 (1978).

66 Id. at 1288.

${ }^{67} I d$.

${ }_{68} I d$. at $1288-90$.

69 United States v. City of Black Jack, 508 F.2d 1179, 1184-85 (8th Cir. 1974), cert. denied, 422 U.S. 1042 (1975).

${ }_{70}$ Metro. Hous. Dev. Corp., 558 F.2d at 1290.

${ }^{71} \mathrm{Id}$. 
and thereby prevents interracial association among members of that community. ${ }^{72}$ The court found that in this case the first type of discriminatory effect was "relatively weak" because $60 \%$ of the persons in the Chicago area who were eligible for federally subsidized housing in 1970 were white. ${ }^{73}$ However, the court held that the second type of discriminatory effect would be established if there was no other land in Arlington Heights which could accommodate the construction of federally subsidized low-income housing because then the effect of the denial of MHDC's request for rezoning would be to perpetuate residential racial segregation in Arlington Heights. ${ }^{74}$ If there was no such other land, the court held that defendants' denial of MHDC's rezoning request would constitute a violation of section 3604(a) of the FHA. ${ }^{75}$ The 1977 Seventh Circuit decision was the first federal court of appeals to hold that a housing decision that perpetuates residential racial segregation in a community can be the discriminatory effect that violates the FHA, independent of the decision's effect on the racial groups protected by the FHA. ${ }^{76}$

\section{HUD'S FHA DISCRIMINATORY EFFECTS RULE}

In 2013, the Secretary of HUD issued a final rule promulgating its standards for determining when a neutral housing practice that has a discriminatory effect gives rise to liability under the FHA. ${ }^{77}$ Initially, HUD pointed out that like eleven federal courts of appeal (including the Seventh Circuit's 1977 decision in the Arlington Heights case), it had long interpreted the FHA to prohibit housing practices with an

72 Id. The court cited Trafficante v. Metropolitan Life Ins., 409 U.S. 205, 209-10 (1972) as support for this second type of discriminatory effect. In Trafficante, the Supreme Court held that a black tenant and a white tenant in an apartment complex had standing under the FHA to challenge the apartment owner's alleged racial discrimination against prospective tenants of the complex. Trafficante, 409 U.S. at 212. The Supreme Court in Trafficante emphasized that the FHA was designed to be applied broadly to promote the integration of the races and to protect communities from discriminatory housing practices that limit interracial association. Id. at 209-12.

73 Metro. Hous. Dev. Corp., 558 F.2d at 1291.

74 Id. at $1291-95$.

75 Id. at $1288,1295$.

76 Id. at $1290,1295$.

77 Implementation of the Fair Housing Act's Discriminatory Effects Standard, 78 Fed. Reg. 11460-501 (Feb. 15, 2013). 
unjustified discriminatory effect, regardless of whether there was an intent to discriminate. ${ }^{78}$

The rule issued by HUD in 2013 defined discriminatory effect as a practice that actually or predictably results in a disparate impact on a group of persons or creates, increases, reinforces, or perpetuates segregated housing patterns because of race, color, religion, sex, handicap, familial status or national origin. ${ }^{79}$ HUD included segregation-perpetuating practices in the definition of discriminatory effect because the "elimination of segregation is central to why the Fair Housing Act was enacted." 80 HUD recognized that the FHA was enacted to not only protect certain groups of persons from discrimination in housing decisions affecting them but also to protect entire communities from residential racial segregation. ${ }^{81}$ Thus, HUD's 2013 rule adopted the principle first developed in the 1977 Seventh Circuit decision in the Arlington Heights case that housing practices that have the effect of perpetuating racial residential segregation in a community are independently actionable under the FHA.

The HUD 2013 rule did alter the FHA legal doctrine developed in the 1977 Seventh Circuit decision in one important way. The 1977 Seventh Circuit decision adopted a four-part balancing test for determining whether a discriminatory effect violates the FHA. ${ }^{82}$ HUD's 2013 rule establishes a three-part burden-shifting test for determining when a housing practice with a discriminatory effect violates the FHA: 1) the alleged victim of discrimination has the burden of proving that a challenged practice caused or predictably will cause a discriminatory effect (i.e., a prima facie case); 2) if a prima facie case is established, the alleged perpetrator of discrimination has the burden of proving that the challenged practice is necessary to achieve one or more substantial, legitimate, nondiscriminatory interests; 3 ) if such an interest(s) is established, the alleged victim of discrimination may still prevail by proving that the interest(s) served by the challenged practice could be served by another practice that has a less discriminatory effect. ${ }^{83}$

\footnotetext{
$78 I d$. at 11460,11462 n. 28.

$79 I d$. at 11467-68, 11482 (codified at 20 C.F.R. $\S 100.500(\mathrm{a})$ ).

80 Id. at 11469.

81 Id.

82 Supra note 47 and accompanying text.

83 Implementation of the Fair Housing Act's Discriminatory Effects Standard, 78 Fed. Reg. at 11482 (codified at 20 C.F.R. $\S 100.500(\mathrm{c})$ ).
} 
HUD's 2013 rule followed the 1977 Seventh Circuit decision in several important respects. HUD accepted that a violation of the FHA could be proven by the discriminatory effect of a housing practice, even absent proof of discriminatory intent. HUD also accepted the 1977 Seventh Circuit decision's holding that a discriminatory effect under the FHA could include a housing practice that perpetuates racial residential segregation in a community, independent of the effect of the practice on the groups that are protected by the FHA. HUD adopted a simplified burden-shifting test for establishing when a discriminatory effect violates the FHA. However, the four evidentiary factors that the 1977 Seventh Circuit decision identified as necessary to evaluate to determine whether a discriminatory effect violates the FHA $^{84}$ are substantive sources of evidence that can be utilized to meet the burden of proof standards in HUD's 2013 burden-shifting test. ${ }^{85}$

\section{SUPREME COURT'S 2015 DECISION IN TEXAS DEPARTMENT OF HOUSING AND COMMUNITY V. ICP}

In 2015, the United States Supreme Court definitively held that disparate-impact claims are cognizable under the FHA. ${ }^{86}$ While the Court acknowledged HUD's issuance of its 2013 rule interpreting the FHA to encompass disparate-impact liability, ${ }^{87}$ the Court did not cite HUD's 2013 rule to support its holding. ${ }^{88}$ Rather, the key factors that supported the Court's holding were the FHA's statutory purpose, its results-oriented text, its 1988 amendments in light of the unanimous view of nine courts of appeal that disparate-impact liability is available under the FHA, and similar statutory language in Title VII of the Civil Rights Act of 1964 and the Age Discrimination in Employment Act of 1967. ${ }^{89}$ The Court acknowledged that government land use practices that exclude minorities from certain neighborhoods could violate the

84 Supra note 47 and accompanying text.

85 Implementation of the Fair Housing Act's Discriminatory Effects Standard, 78 Fed. Reg. at 11482 .

86 Tex. Dep't of Hous. \& Cmty. v. Inclusive Cmtys. Project, Inc., 135 S. Ct. 2507, 2525 (2015).

87 Id. at 2514.

88 Id. at $2516-25$.

$89 I d$. at 2525 . 
FHA, ${ }^{90}$ citing two cases, United States v. City of Black Jack ${ }^{91}$ and Huntington Branch, NAACP v. Town of the Huntington, ${ }^{92}$ both of whose rationales for finding FHA violations included that the challenged housing practices perpetuated segregation in the affected communities. $^{93}$

The Court also recognized that prejudice is often unconscious and animus is often disguised and that disparate-impact liability prevents these factors from contributing to "segregated housing patterns that might otherwise result from covert and illicit stereotyping."94 Finally, the Court was emphatic that the FHA should be interpreted to promote its "continuing role in moving the Nation toward a more integrated society." 95

In holding that disparate-impact claims are cognizable under the FHA, the Court did note several limitations on its holding. The Court cautioned that serious constitutional questions might arise if disparity-impact liability under the FHA was based solely on a statistical disparity. ${ }^{96}$ If evidence of statistical disparities are offered as proof of disparate impact, it must be established that the disparities are caused by a policy of the alleged perpetrator of discrimination. ${ }^{97}$ If a housing discrimination claim based on a disparate-implicit liability is brought, the alleged perpetrator must also be able to present a valid interest served by the challenged policy as a defense to the discrimination claim. Finally, the Court cautioned against race being applied as a quota in a disparate-impact context because this would implicate constitutional issues and would frustrate efforts to develop race-neutral solutions to housing problems. ${ }^{98}$

\section{RECONSIDERATION OF HUD'S IMPLEMENTATION OF THE FAIR HOUSING ACT'S DisPaRATE IMPACT STANDARD}

In June 2018, HUD announced that it intended to consider possible amendments to HUD's 2013 rule implementing the FHA's

\footnotetext{
$90 \quad I d$. at 2521-22.

91508 F.2d 1179, 1186 (8th Cir. 1974), cert. denied, 422 U.S. 1042 (1975).

92844 F.2d 926, 937-38 (2d Cir. 1988), judgment aff'd in part, 488 U.S. 15 (1988).

93 City of Black Jack, 508 F.2d at 1186; Huntington Branch, 844 F.2d at 937-38.

94 Tex. Dep't of Hous. \& Cmty., 135 S. Ct. at 2522.

95 Id. at 2525-26.

$96 \quad I d$. at 2522.

97 Id. at $2522-24$.

98 Id. at 2523-25.
} 
disparate impact standard. ${ }^{99}$ HUD is reviewing the 2013 rule to determine if it should be revised in light of the United States Supreme Court's 2015 decision in Texas Department of Housing and Community v. ICP. ${ }^{100}$

It is unlikely that HUD will disturb the perpetuation-ofsegregation basis of discriminatory effect liability under the FHA embodied in its 2013 rule ${ }^{101}$ because the Supreme Court in its 2015 decision recognized that one of the primary purposes of the FHA is to combat residential segregation in the Nation. ${ }^{102}$ The perpetuation-ofsegregation basis of discriminatory effect liability under the FHA has been successful at challenging zoning or other actions of local governments that block the construction of affordable housing developments. ${ }^{103}$ In its 2015 decision, the Supreme Court described suits that target such local governmental practices as the "heartland of disparate-impact liability" under the FHA. ${ }^{104}$ Any efforts by HUD to undermine perpetuation-of-segregation claims as a basis for disparateimpact liability under the FHA would be inconsistent with the Supreme Court's 2015 decision.

The limitations included in the Supreme Court's 2015 decision about the application of disparate-impact liability under the FHA ${ }^{105}$ apply to perpetuation-of-segregation claims. ${ }^{106}$ How these limitations would apply to a perpetuation-of-segregation claim like the Arlington Heights case can be examined in the context of HUD's current threepart burden-shifting test for determining when a housing practice with a discriminatory effect violates the FHA. ${ }^{107}$

Part 1. The alleged victim of discrimination has the burden of proving that a practice of the alleged perpetrator of discrimination caused a segregated housing pattern to be created, increased, reinforced or perpetuated. ${ }^{108}$ A limitation on disparate-impact liability

\footnotetext{
99 Reconsideration of HUD's Implementation of the Fair Housing Act's Disparate Impact Standard, 83 Fed. Reg. 28560-601 (June 20, 2018).

$100 \mathrm{Id}$. at 28560.

101 Implementation of the Fair Housing Act's Discriminatory Effects Standard, 78 Fed. Reg. 11482 (Feb. 15, 2013) (codified at 20 C.F.R. $§ 100.500(a)$ ).

102 Tex. Dep't of Hous. \& Cmty., 135 S. Ct. at 2525-26.

103 Robert G. Schwemm, Segregative-Effect Claims under the Fair Housing Act, 20 N.Y.U. J. LeGis. \& PUB. POL'y 709, 749-50 (2017).

104 Tex. Dep't of Hous. \& Cmty., 135 S. Ct. at 2521-22.

105 Supra notes 96-98 and accompanying text.

106 Schwemm, supra note 103, at 728-29.

10720 C.F.R. $\$ 100.500$ (c) (2019).

108 Id. $\S 100.500(\mathrm{a}),(\mathrm{c})(1)$.
} 
under the FHA imposed by the Supreme Court that applies here is that a disparate-impact claim that relies on a statistical disparity should fail if the plaintiff cannot identify an alleged perpetrator's policy that caused the disparity. ${ }^{109}$ Thus, the Supreme Court emphasized that an alleged perpetrator's policy must cause residential segregation to be perpetuated in the affected community.

In the Arlington Heights case, all of the elements necessary for plaintiffs to meet their burden of proof at part one existed. The 1977 Seventh Circuit decision relied on population statistics to establish that Arlington Heights was a racially segregated community —in 1970, it had a population of 64,884 of whom only 27 were black. ${ }^{110}$ MHDC's planned low-income housing development would have reduced racial segregation in Arlington Heights because it was to be subsidized by the federal government which required the development to be racially integrated. ${ }^{111}$ When Arlington Heights denied MHDC's rezoning request, the effect was to perpetuate segregation in Arlington Heights. ${ }^{112}$

A policy of Arlington Heights was at the heart of its denial of MHDC's rezoning request. MHDC's rezoning request was denied because it would violate Arlington Heights' land use policy of only allowing R-5 (multi-family housing) zoning as a buffer between single family homes and commercial, industrial and other high intensity uses. ${ }^{113}$ The land that MHDC sought to rezone to R-5 was surrounded by single family homes ${ }^{114}$ and to rezone it would have violated Arlington Heights' R-5 buffer policy.

Finally, the 2015 Supreme Court decision requires that the implementation of the alleged perpetrator's policy must cause the perpetuation-of-segregation effect. ${ }^{115}$ HUD's current regulation involving discriminatory effects under the FHA includes the causation requirement. ${ }^{116}$ In the 1977 Seventh Circuit decision, the court found that Arlington Heights' decision to deny MHDC's zoning request "had

\footnotetext{
109 Tex. Dep't of Hous. \& Cmty., 135 S. Ct. at 2523.

110 Metro. Hous. Dev. Corp. v. Vill. of Arlington Heights, 558 F.2d 1283, 1286-87 (7th Cir. 1977), cert denied, 434 U.S. 1025 (1978).

111 Id.

112 Id.

113 Supra note 20 and accompanying text.

114 Supra note 12 and accompanying text.

115 Tex. Dep't. of Hous. \& Cmty. v. Inclusive Cmtys. Project, Inc., 135 S. Ct. 2507, 2523 (2015).

11620 C.F.R. $\$ 100.500(c)(1)(2019)$.
} 
the effect of perpetuating segregation in Arlington Heights." 117 The Seventh Circuit found causation so MHDC and the other plaintiffs could have established what is now described as a "prima facie case" 118 at part one of the burden-shifting process used by HUD to determine whether a discriminatory effect violates the FHA.

Part 2. If the alleged victim of discrimination proves a prima facie case at part one, the alleged perpetrator of discrimination must prove at part two that its policy is necessary to achieve one or more substantial, legitimate, nondiscriminatory interests. ${ }^{119}$ This part is consistent with the limitation in the Supreme Court's 2015 decision that alleged perpetrators of discrimination must be given "leeway to state and explain the valid interest served by their policies." 120

In the Arlington Heights case, defendants could likely prove that the buffer policy in Arlington Heights' land use laws that was the reason for the denial of MHDC's rezoning request ${ }^{121}$ was a substantial, legitimate, nondiscriminatory interest that met their burden of proof at part two. None of the courts that considered the Arlington Heights case questioned whether Arlington Heights' R-5 buffer policy was a legitimate land use policy.

Part 3. If the alleged perpetrator of discrimination meets its burden of proof at part two, the alleged victim of discrimination must prove at part three that the substantial, legitimate, nondiscriminatory interest proved in part two could be served by another practice that has a less discriminatory effect. ${ }^{122}$ Part three is analogous to the provision of the Title VII statute that a party complaining of alleged employment discrimination on a disparate-impact theory of liability can rebut an employer's defense to an employment discrimination charge by proving that an alternative employment practice exists that would eliminate the disparate impact. ${ }^{123}$

In the Arlington Heights case, the 1977 Seventh Circuit decision explored alternatives to building MHDC's low-income housing project at sites other than the one for which it sought rezoning that would not violate Arlington Height's buffer zone policy for

\footnotetext{
117 Metro. Hous. Dev. Corp., 558 F.2d at 1288.

118 Implementation of the Fair Housing Act's Discriminatory Effects Standard, 78 Fed. Reg. 11460 (Feb. 15, 2013).

11920 C.F.R. $\S 100.500(\mathrm{c})(2)$.

120 Tex. Dep't of Hous. \& Cmty., 135 S. Ct. at 2522.

121 Supra notes 20, 113-14 and accompanying text.

12220 C.F.R. $\S 100.500(\mathrm{c})(3)$.

12342 U.S.C. 2000(e)-2(k)(1)(A)(ii) (2018).
} 
locating multifamily housing. ${ }^{124}$ The court remanded the case to the district court to require Arlington Heights to identify any other such sites that are both zoned R-5 and are suitable for federally-subsidized, low-income housing. ${ }^{125}$ After the case was remanded by the Seventh Circuit in 1977, the parties settled the case in the district court agreeing to an alternative site for MHDC's housing development. ${ }^{126}$ Pursuant to the settlement, MHDC developed its federally-subsidized, lowincome housing development at an alternative site in Arlington Heights, and it opened for occupancy in 1983 to a diverse population of residents. ${ }^{127}$ Thus, MHDC and Arlington Heights were able to agree on an alternative site for MHDC's low-income housing development that was both consistent with Arlington Heights' R-5 buffer policy and achieved MHDC's and the FHA's goal of reducing residential segregation in Arlington Heights. As a result, the Arlington Heights case would have been actionable under HUD's 2013 rule for determining disparate impact liability under the FHA while honoring the limitations imposed on such liability by the Supreme Court in its 2015 decision.

\section{CONCLUSION}

The protracted litigation between MHDC and Arlington Heights resulted in several significant legal decisions. The Supreme Court held that residential racial discrimination only violates equal protection if it is purposeful. On remand from the Supreme Court, the Seventh Circuit recognized disparate-impact liability under the FHA and held that a housing decision that perpetuates residential racial segregation in a community is the type of discriminatory effect that can be actionable under the FHA even absent discriminatory purpose. The Seventh Circuit also recognized that the FHA has dual purposes to prevent discrimination on the basis of race and other protected characteristics and to avoid the perpetuation of racial residential segregation in American communities. Maintaining the perpetuationof-segregation theory of disparate-impact liability under the FHA is consistent with both HUD's 2013 rule and the Supreme Court's 2015

\footnotetext{
124 Metro. Hous. Dev. Corp. v. Vill. of Arlington Heights, 558 F.2d 1283, 1291-95 (7th Cir. 1977), cert denied, 434 U.S. 1025 (1978).

125 Id. at $1294-95$.

126 Supra notes 52-58 and accompanying text.

127 Supra notes 60-62 and accompanying text.
} 
decision in Texas Department of Housing and Community v. ICP. Its application in the Arlington Heights case resulted in the construction of an integrated housing development that furthered one of the primary purposes of the FHA - the promotion of the residential integration of the races in the United States. 